\title{
Requirement Engineering Method for Alignment of Information Technology (IT) Utilization with Education Business Strategy
}

\author{
Budi Laksono Putro ${ }^{1}$, Heri Sutarno ${ }^{2}$, Rizky Rachman Judhie Putra ${ }^{3}$, Della Ilona Suryana \\ Putri $^{4}$ \\ \{budilp@upi.edu, herisutarno@upi.edu,risky_rjp@upi.edu\} \\ Universitas Pendidikan Indonesia ${ }^{1,2,3,4}$
}

\begin{abstract}
Information technology is widely used in work management because of its effectiveness and efficiency which have been proven to be able to accelerate performance. The problem is that there are often differences between the initial requirements and the actual requirements the customer wants. To solve these problems an engineering approach was implemented which eventually became Requirements Engineering. This research was made using the WebQual 4.0 method with three main dimensions of WebQual namely Usability, Information Quality and Service Interaction. From the calculation process the results obtained from the usability variable of 3,797 with an average of 474,625 and the Information Quality variable is 3215 with an average of 459.28 which means that the information conveyed through the SPOT system is of high quality, Service Interaction Quality variable of 3097 with an average of 442.42, which means that the SPOT system service is of high quality.
\end{abstract}

Keywords: Requirement Engineering, WebQual 4.0, Usability, Information Quality, Service Interaction

\section{Introduction}

One of the reasons Information Technology is widely used in work management is its effectiveness and efficiency which have been proven to be able to accelerate performance. Speed of performance is what will increase profits or turnover that enters financially and in a network. That can provide benefits for an organization. However, to achieve this we need a good and correct IT management.

In general, a program can run effectively if it has a good governance system. Likewise, IT management requires information technology governance. Information technology governance is defined as a collection of policies, processes/activities and procedures to support the operation of information technology so that the results are in line with the business strategy (organizational strategy) [1]. In addition, Information Technology Governance can be regarded as a map of the alignment of an organization's business strategy in the form of an Information Technology governance portfolio [1].

But frustration often occurs on both the developer and customer side because the developer feels a significant difference between the initial requirements and the actual requirements desired by the customer. This will certainly add additional costs and slower processing time. On the other hand, customers are also frustrated because they feel they have 
explained their wishes very clearly, but the developer cannot understand them well. To solve this problem an engineering approach was implemented which eventually became Requirements Engineering.

Requirements engineering is the initial stage of the process of implementing an information system that is a collection of various requirements that are understood and determined. Software engineering experts agree that requirements engineering is a very important job. Facts prove that most software development failures are caused by things in the form of inconsistencies, incompleteness or incorrectness of requirements specifications [2].

The system used in this study is one of the systems found at Universitas Pendidikan Indonesia, called the Integrated Online Learning System (SPOT). This system is a web-based application system that can be used to replace face to face or as a complement to learning. However, at the time of implementation, there are some features that are not yet in accordance with the needs of the user, causing repetition in the analysis and design stages. This is because the needs analysis process has not been done properly.

Based on these problems, research was made on Requirement Engineering with the WebQual method. This research will be carried out by reviewing the requirements specifications that have been made in the process of making software by structuring and validating it to produce better requirements specifications. With this method being implemented it is expected to produce software that suits the needs of users.

This study uses the WebQual 4.0 [3] method with three main dimensions of WebQual 4.0, namely Usability, Information Quality, Service Interaction. This research was conducted using a questionnaire and tested through a classic assumption test and regression analysis. The population of this study were students and lecturers of the Indonesian University of Education.

\section{Research Methods}

This study uses the WebQual 4.0 method with three main dimensions of WebQual 4.0 which have been explained before, namely Usability, Information Quality, Service Interaction. The instrument uses a questionnaire and is tested through a classic assumption test and regression analysis. The population of this study were students and lecturers of the Indonesian Education University and obtained 150 respondents. The research design is shown on Figure 1. 


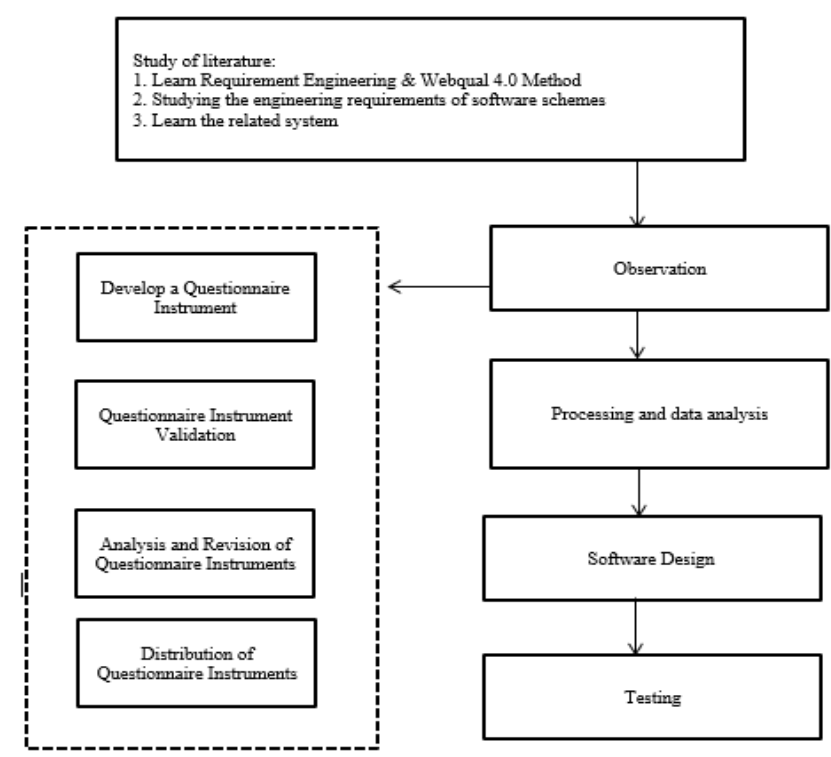

Fig. 1. Research Design

\subsection{Observation}

At this observation stage, it is done by compiling several questionnaire instruments, validating the questionnaire instrument, after conducting validation analysis and improvement of the questionnaire are conducted. Then the instrument is validated and the instrument is ready to be distributed. This study uses the WebQual 4.0 model and is structured based on three areas namely usability, information quality and interaction quality. In collecting questionnaire or questionnaire data used to obtain information from respondents. The type of questionnaire used types an optional questionnaire that asks respondents to choose an answer, one answer that has been determined. For alternative answers in this questionnaire, a score is given for each option using a Likert scale modification. Thus in this study respondents in answering questions, there are only 4 categories including strongly agree (SS), agree (S), disagree (TS), strongly disagree (STS) [4].

To determine the scale range, the equation (1) used is [4] :

$$
\mathrm{RK}=\frac{n(m-1)}{m}
$$

information:

$\mathrm{n}=$ number of samples

$\mathrm{m}=$ number of alternative answers per item

Based on the formula above, a range of scales is obtained below: 


\subsection{Data Processing and Analysis}

This stage consists of testing the validity of using Bevariate Pearson correlation and reliability using Cronbach's alpha test on the results of the questionnaire. Then the classic assumption test and regression analysis are performed and then interpret the results of the analysis. At the software design stage, the design and manufacture of software engineering and the results of the research are carried out. It is a testing phase of software that is built as a whole so that all systems can be sure to run properly and correctly in accordance with the original purpose.

\section{Results and Discussion}

This chapter discusses data processing including; validity and reliability tests, discussion of data processing, and data processing analysis

\subsection{Validity and Reliability Test}

After obtaining data from the results of the student respondents continued with the validity and reliability test. With the following data as can be seen on Table 1 .

Table 1. Validity Test.

\begin{tabular}{|c|c|c|c|c|c|}
\hline \multirow{2}{*}{$\begin{array}{c}\begin{array}{c}\text { Item } \\
\text { Question }\end{array} \\
1\end{array}$} & \multicolumn{2}{|c|}{ Result } & \multirow{2}{*}{$\begin{array}{c}\begin{array}{c}\text { Item } \\
\text { Question }\end{array} \\
16\end{array}$} & \multicolumn{2}{|c|}{ Result } \\
\hline & 0.439 & Valid & & 0.793 & Valid \\
\hline 2 & 0.627 & Valid & 17 & 0.609 & Valid \\
\hline 3 & 0.538 & Valid & 18 & 0.508 & Valid \\
\hline 4 & 0.666 & Valid & 19 & 0.652 & Valid \\
\hline 5 & 0.646 & Valid & 20 & 0.743 & Valid \\
\hline 6 & 0.705 & Valid & 21 & 0.686 & Valid \\
\hline 7 & 0.690 & Valid & 22 & 0.727 & Valid \\
\hline 8 & 0.472 & Valid & & & \\
\hline 9 & 0.687 & Valid & & & \\
\hline 10 & 0.659 & Valid & & & \\
\hline 11 & 0.752 & Valid & & & \\
\hline 12 & 0.720 & Valid & & & \\
\hline 13 & 0.750 & Valid & & & \\
\hline 14 & 0.794 & Valid & & & \\
\hline 15 & 0.800 & Valid & & & \\
\hline
\end{tabular}

This validity test is done by comparing the $r$ count numbers and $r$ tables. If $r$ count is freer than $r$ table then the item is said to be valid and vice versa if $r$ count is smaller than $r$ table then the item is said to be invalid. Table $\mathrm{r}$ for the following validities is 0.159 . then the item is said to be valid because of the validity value $>r$ table as shown on Table 2 . 
Table 2. Reliability Tests.

\begin{tabular}{cccc}
\hline Variable & Reliabilities Coefficient & Cronbach Alpha & Result \\
\hline Usability & 8 Item question & 0.826 & Reliable \\
$\begin{array}{c}\text { Quality } \\
\text { Information }\end{array}$ & 7 Item question & 0.903 & Reliable \\
$\begin{array}{c}\text { Service } \\
\text { Interaction }\end{array}$ & 7 Item question & 0.866 & Reliable \\
\hline
\end{tabular}

From the table above it can be seen that each variable has a Cronbach Alpha> 0.60. Thus the variables (Usability, Quality Information, and Service Interaction) can be said to be reliable.

\subsection{Discussion of Data Analysis Results}

We can see that the tolerance value is more than 0.1 and the VIF value is smaller than 10 , so there is no multicollinearity in this study as shown on Table 3.

Table 3. Multicollinearity Results

\begin{tabular}{lll}
\hline Variable & Tolerance & VIF \\
\hline Usability & 0.409 & 2.442 \\
Quality Information & 0.314 & 3.187 \\
Service Interaction & 0.420 & 2.380 \\
\hline
\end{tabular}

Analysis based on Scatterplots output above is known that the data spread points are above and below or around the number 0 and do not form wavy patterns (Figure 2). Thus we can conclude that there is no heteroscedasticity problem so that a good and ideal regression model can be fulfilled.

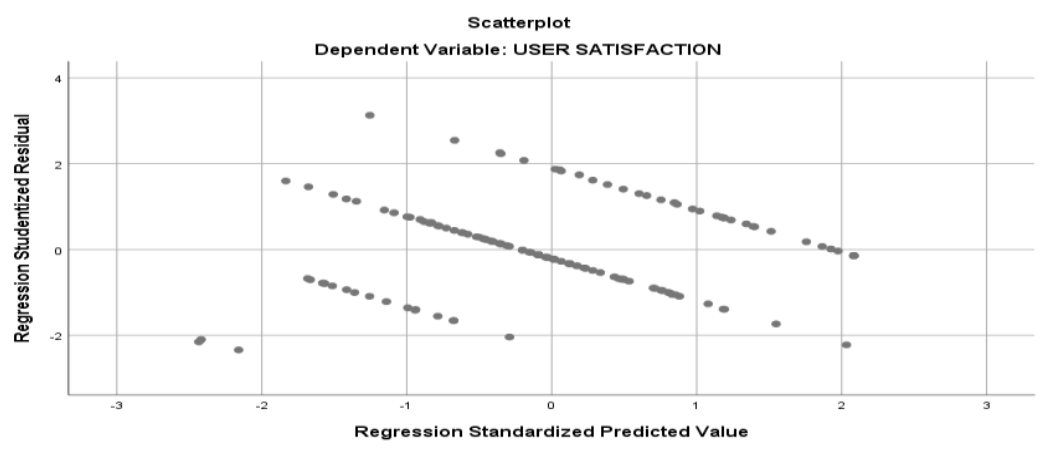


Fig. 2. Scatterplot

Because $\mathrm{du}<\mathrm{d}<4-\mathrm{du}=1,845<1665<2,335$ it can be stated that autocorrelation does not occur because it meets the requirements. Based on the output "chart" above, the plotting points contained in the picture (Figure 3) always follow and approach the diagonal line. Therefore decision making in the normality test can be concluded that the residual value is normally distributed. Thus, the assumption of normality for the residual value in this study can be fulfilled.

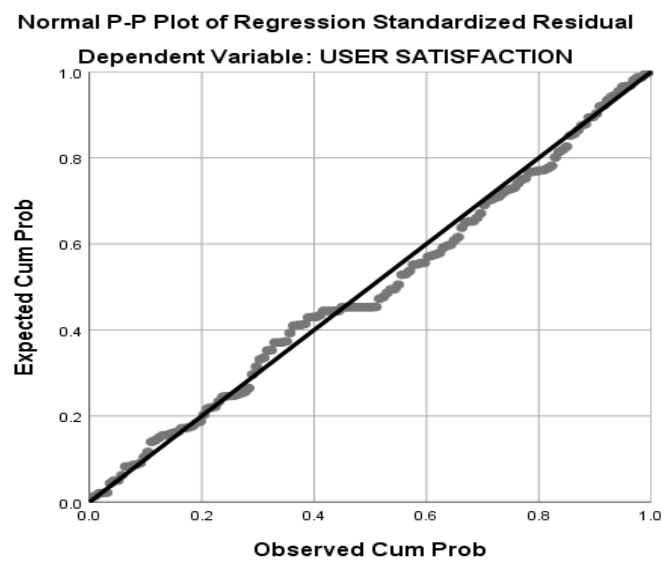

Fig. 3. Probability Plot Test Results

Based on the results of the Table 7 below we get the multiple linear regression equation as follows:

$\mathrm{Y}=0.25+0.051 \mathrm{X} 1+0.024 \mathrm{X} 2+0.073 \mathrm{X} 3$ it can be concluded that:

1. Constant value of 0.025 . This means that if the website quality variables (usability, information quality, service interaction quality) remain then user satisfaction (Overall) is 0.025 .

2. The coefficient value X1 (Usability) of 0.051. This means that each addition of one unit to usability results in increased user satisfaction by 0.051 assuming that the other website quality variables from the regression model are fixed.

3. Value coefficient X2 (Information Quality) of 0.024. This means that each addition of one unit of information quality results in increased user satisfaction by 0.024 assuming that the other website quality variables from the regression model are fixed.

4. Coefficient value X3 (Service Interaction Quality) of 0.073. This means that each addition of one unit of service interaction quality results in increased user satisfaction by 0.073 .

Hypothesis 1. Based on the analysis of the data from Table 8 below, it can be seen that the $t$ count for the Usability variable is 3.011. This value is above the table value of 1.977 and a significance value of $0.03<0.05$. So Ho is rejected and $\mathrm{H} 1$ is accepted, meaning that Usability has a significant positive effect on user satisfaction. 
Hypothesis 2. Based on the Table 8 data analysis, it can be seen that $t$ arithmetic for the Information Quality variable is 1.244. This value is below the t table value of 1.977 and a significance value of $0.216>0.05$. Then Ho is accepted and $\mathrm{H} 1$ is rejected, meaning that Information Quality on the SPOT system does not affect user satisfaction.

Hypothesis 3. Based on the analysis of the data Table 8, it can be seen that arithmetic for the Information Quality variable is 4.023. This value is above the t table value of 1,977 and a significance value of $0,000<0.05$. So $\mathrm{Ho}$ is rejected and $\mathrm{H} 1$ is accepted, meaning that Usability has a significant positive effect on user satisfaction.

The F test Table 4 shows that the calculated $F$ value of 46,766 with a significance level of 0,000 . When referring to table F with df1 (k-1) and def2 (n-k), an F table of 3.09 is obtained. When compared, the F count is 46.766> F table. Then when viewed from the level of significance, where the significance value obtained is $0,000<0.05$ then there is a significant effect. Therefore it can be explained that there is a significant influence of Usability, Information quality and Service interaction quality on user satisfaction.

Table 4. F Test Anova

\begin{tabular}{lrrrrr}
\hline \multicolumn{5}{c}{ ANOVA } \\
Model & Sum of Squares & df & Mean Square & F & Sig. \\
\hline 1 Regression & 32.098 & 3 & 10.699 & 46.766 & $.000^{\mathrm{b}}$ \\
Residual & 33.402 & 146 & .229 & \\
Total & 65.500 & 149 & & \\
a. Dependent Variable: USER SATISFACTION & \\
b. Predictors: (Constant), SERVICE, USABILITY, QUALITY \\
\hline
\end{tabular}

Based on Table 5 below, the R-value is 0,700 (70\%) and R Square is 0,490 (or 49.0\%). This shows that the percentage contribution of the influence of independent variables (usability, information quality, service interaction quality) on the dependent variable (user satisfaction / Overall) by $49.0 \%$. Or the contribution of all independent variables to the dependent variable simultaneously is $49.0 \%$. While the remaining $51 \%$ is contributed by factors other than factors not included in this research model.

Table 5. Test results of multiple correlations (R) and Determination (R2)

\begin{tabular}{lrrrrr}
\hline \multicolumn{5}{c}{ Model Summary } \\
Model & $\mathrm{R}$ & R Square & Adjusted R Square & Std. Error of the Estimate & Durbin-Watson \\
\hline 1 & $.700^{\mathrm{a}}$ & .490 & .480 & .478 & 1.845 \\
a. Predictors: (Constant), SERVICE, USABILITY, QUALITY & & \\
b. Dependent Variable: USER SATISFACTION & & &
\end{tabular}

\subsection{Analysis and Discussion}


Based on the results explained, an analysis of the research conducted on the SPOT application can be explained as follows:

1. The effect of the Usability variable on satisfaction. SPOT users namely states Usability has a significant positive effect on user satisfaction.

2. The effect of the Information Quality variable on SPOT user satisfaction that states Information Quality on the SPOT system does not affect user satisfaction (user satisfaction)

3. The effect of Service Interaction Quality variable on SPOT user satisfaction, namely stating Service Interaction Quality has a significant positive effect on user satisfaction.

4. There is a significant influence of Usability (ease of use), Information Quality (information quality) and Service Interaction Quality (service quality) on user satisfaction (user satisfaction).

5. Overall, the more dominant factor influencing user satisfaction for SPOT services is the Service interaction quality variable, 0.367 , the Usability variable 0.278 , and the Information Quality variable 0.131 . So it can be concluded that the more dominant influence on user satisfaction for SPOT services is the Service Interaction Quality variable that is $36.7 \%$ while for the Usability variable $27.8 \%$ and the Information Quality variable $13.1 \%$.

6. Based on the descriptive analysis that has been done, the average score for the usability variable is 474,625 , which when referring to the scale range table is in the agreed category, which means that SPOT users are easy to use among students and lecturers at Indonesian university of education.

7. Based on the descriptive analysis that has been done, the average score obtained for the Information Quality variable is 459.28 , which when referring to the scale range table is included in the agreed category, which means that the information submitted on the SPOT system is of high quality.

Based on the descriptive analysis that has been done, the average score for the Service Interaction Quality variable is 442.42 , which when referring to the scale range table is included in the agreed category, which means the service interaction in the SPOT system can be said to be of quality.

\section{Conclusion}

The results of this study can be used as an illustration of the quality of academic websites, in this case, the existing SPOT system. In addition, the results of this study can also be a reference material for universities in an effort to improve the quality of their academic websites. This research has added references to the use of the Webqual 4.0 method to measure website quality. Methodologically, this research also plays a role in encouraging the use of quantitative methods. Based on the results of calculations that of the three variables namely Usability variable obtained an average of 459.28 which can be said that the SPOT system is easy to use among students and lecturers. Information Quality variable obtained an average of 459.28 it can be said that the information conveyed through the SPOT system is of high quality and Service Interaction Quality Variable obtained an average of 442.42, it can be said that the SPOT system service is of high quality. 
Acknowledgments. All praise is the presence of Allah SWT for His blessings and gifts. I thank those who have contributed to this research, namely: parents, family, friends, UPI Computer Science Department, and the Indonesian Ministry of Research and Technology.

\section{References}

[1] Ananda, E. D.: Pemanfaatan Teknologi Informasi, 5(20), pp.14 (2003)

[2] Arayici, Y., \& Aouad, G.: Computer integrated construction: an approach to requirements engineering. Engineering, Construction and Architectural Management, 12(2),. pp.194-215. (2005)

[3] Hofmann, H. F., \& Lehner, F.: Requirements engineering as a success factor in software projects, (August), pp.7459 (2001)

[4] Hull, E., Jackson, K., \& Dick, J.: Requirements Engineering. Requirements Engineering (Vol. 13). (2006)

[5] Islam, U., Syarif, N., \& Jakarta, H.: Framework dan prototype tata kelola TI, 2(1), pp.41-49. (2009)

[6] Kabaale, E., \& Kituyi, G. M.: A theoretical framework for requirements engineering and process improvement in small and medium software companies. Business Process Management Journal, 21(1),. pp.80-99. (2015)

[7] Kadir, A., \& Triwahyuni, T. (2014). Pengantar Teknologi Informasi Edisi Revisi, (January), 2. https://doi.org/10.13140/2.1.4734.7840

[8] Kuswardani Mutyarini, S.: Arsitektur Sistem Informasi Untuk Institusi Perguruan Tinggi Di Indonesia. pp.102-107 (2015)

[9] Sommerville, I., \& Sawyer, P.: Requirements Engineering - A Good Practice Guide, pp. 404 (2003)

[10] Wahono, R. S.: I j w - 200 3. Proceedings of the IECI Japan Workshop 2003, 5(2), pp.55-58 (2003)

[11] Nawangsari, A. Y.:Structural Equation Modeling pada Perhitungan Indeks Kepuasan Pelanggan dengan Menggunakan Software Amos. Universitas Negeri Yogyakarta (2011)

[12] Vaulla, T. S., Agustin, W., \& Dania, P. (2013). Analisis Persepsi Konsumen Terhadap Ekuitas Merek Menggunakan Metode Structural Equation Modeling (Sem) (Studi Kasus Pada Rumah Makan “ Mie Jogja Pak Karso ” Malang ).

[13] Ghozali I Dan Fuad.: 2005. Structural Equation Modelling (Teori, Konsep, Dan Aplikasi). Badan Penerbit Universitas Diponegoro. Semarang. pp. 3, 1-8.9 (2005)

[14] Putri, G. I.: Analisis Harga, Kualitas Produk, Dan Kualitas Pelayanan Terhadap Keputusan Pembelian Yang Mempengaruhi Loyalitas Pengecer Bumbu Tabur Venus Di Kota Semarang. Universitas Dian Nuswantoro Semarang, (1), pp.1-15 (2015)

[15] Zuhri, S., Andriansyah, A., Asmadi, D., \& Khajar, S.: Analisis Loyalitas Pelanggan Industri Jasa Pengiriman Menggunakan Structural Equation Modeling. Jurnal Ilmiah Teknik Industri, 15(2), 101 (2017).

[16] Putro, B. L., Surendro, K., \& Herbert, H.: Leadership and culture of data governance for the achievement of higher education goals (Case study: Indonesia University of Education). AIP Conference Proceedings, 1708(2012) (2016)

[17] Arikunto, Suharsimi.: Metodologi Penelitian. Penerbit PT. Rineka Cipta. Jakarta (2002)

[18] Barnes, S.J. and Vidgen, R.T.: Assessing E-Commerce Quality with WebQual: An Evaluation of the Usability, Information Quality, and Interaction Quality of Internet Bookstores. Journal of Electronic Commerce Research, 3, 114-127 (2002) 